\title{
THREE SPECIES OF EMPOASCA LFAFHOPPERS KNOWN TO AFFECT ECONOMIC PLANTS IN HAITI (INCLUDING THE DESCRIPTION OF TWO NEW SPECIES)*
}

\author{
By Dwight M. DeLosg \\ Professor of Entomology, Ohio State University
}

For many years it has been the opinion of entomologists that Empoasca fabae Harris, the potato leafhopper was a pest occurring in all parts of the United States and Central and South America. Recently the writer ${ }^{1}$ has been able to distinguish the species of Empoasea by the male genital pieces and has then shown by field studies ${ }^{2}$ that other important species are concerned and that these instead of fabae are the important economic forms in certain areas of the United States. Following this study of eharacters, Dr. R. C. Smith then located at Port-au-Prince, Haiti, forwarded to the writer a large series of specimens collected from beans and sweetpotatoes in that locality. Upon examination it was found that these were not fabae and the species was described as E. fabalis DeL." According to the survey made by Dr. Smith when these specimens were collected the speeies was extremely abundant upon beans anr sweetpotatoes and was considered the most important species of economic leafhopper in Haiti upon truck erops.

More recently Dr. H. L. Dozier forwarded three different lots of material collected in the same area one of which has proven to be fabalis which he collected from sweetpotatoes. The other two species, one collected firom cotton and another from Canavalia are apparently undescribed. There is a possibility therefore that the three have been considered as one species and each of these may be important economically. The descriptions together with an illustration of the male genital structures of each are included below.

Empoasca fabalis DeLong.

Canadian Entomologist LXII p. 92 April 1930.

Resembling fabae in size, form and appearance but with distinet genital characters. Length $3 \mathrm{~mm}$.

* Editor's Note: E. fabalis is widely distributed and injurious to lima and string beans in Puerto Rico and has also been reported as injurious to tomato. The species commonly present on sweet potato here has not us yet been specifically determined but is quito probably fabalis. The cotton leafhopper in Porto Rico may also be $E$. gossypit herein deseribed as new.

1 U. S. D. A. Tech. Bult. 231, January, 1931.

$\therefore$ I. Jour. Eco. Ent. Vol. 24, p. $475-480$, April, 1931.

- Canadian Entomologist LXIr, p. 92, April, 1030. 
Vertex strongly produced about one-third its length before anterior margins of eyes. One-third wider between eyes than length at middle. Pronotum onethird longer than vertex.

Color pale green without distinct markings. Usually with irregular mottling and varying longitudinal stripes, white. A pair of oblique dark green spots either side of, and back of apex,

Genitalia: Female last ventral segment roundingly produced and entire. Male valve twice as long as preceding segment, posterior margin almost truncate. Plates long and narrow, gradually tapered to rather acute tips, more than twice as long as valve.

Male internal genital structures: In ventral view styles short, slender, very narrow at apices which are bent outwardly. Lateral processes of pygofers long and tapered. Apieal fifth very narrow and slightly bent inwardly (in ventral view). Dorsal spines of pygofers heavy at base but rapidly narrowed to ventrally directed and slightly anteriorly hooked processes.

\section{Empoasca gossypii new species.}

Appearance and general form of fabae but smaller and with distinct male genitalia. Length $2.8 \mathrm{~mm}$.

Vertex almost one-third wider between eyes than length at middle. Pronotum two-fifths wider than long. Humeral angles prominent, posterior margin strongly concave.

Color greenish marked with white and yellow. Vertex yellowish green mottled with white. Pronotum yellowish, subhyaline. Anterior and lateral margins marked with white. Seutellum mostly white. Elytra greenish, subhyaline with yellowish green longitudinal stripping sometimes very faintly colored.

Genitalia: Female last ventral segment as long as basal width. Posterior margin with lateral angles rounded and slightly indented either side of a median slightly produced broadly angled lobe which is about half the width of the segment. Male plates more than two and one-half times as long as combined width at base rapidly narrowed to compressed, flaring, and upturned apices. Ventrally set with long brownish spines.

Male internal genital structures: Styles strongly curved outward apically in ventral view. Lateral processes of pygofers short and rather stout, gently curved dorsally. Dorsal spines of pygofers wide at base curved ventrally, bifureate apically.

This is the only species of Empoasca except bifurcata, a common species in the Eastern United States, which is known to have a bifurcate dorsal spine. It can easily be distinguished from the other deseribed species in Haiti by this character.

Described from 35 female and male specimens collected from cotton at Hinche, Haiti, September 12, 1931, by Dr. H. L. Dozier.

Holotype male labeled Hinche, Haiti, September 12, 1931.

Empoasca canavalia new species.

Resembling fabae in general appearance but smaller and with distinct male and female genital characters. Length $2.8 \mathrm{~mm}$. 
Vertex bluntly angularly produced almost one-third wider between eyes than length at middle. Pronotum more than twice as wide as long. Elytra exceeding abdomen by about one-fourth their length.

Color variable, usually some shade of green. Vertex yellowish or orange yellow marked with green. Two rather bright green areas on dise either side of vertex. Pronotum and elytra greenish subhyaline.

Genitalia: Female last ventral segment two-thirds as long as basel width. Posterior margin concavely rounded to produced central tooth which is more than one-third the width of the segment and is slightly notched at center. Male plates one-third longer than combined width at base apices rather sharply pointed and upturned. Sides straight.

Male internal genital structures: In ventral view styles gently curved outwardly. Lateral processes of pygofers as seen in lateral view rather broad, constricted near apex and terminated by a slender curved finger process. Dorsal spines of pygofers large, broad at base, produced downward and inwardly, appearing to eross each other in ventral view, gradually tapering to pointed tips.

Described from 48 female and male specimens collected from Jack Bean, Canavalia ensiformis (L) D. C. at Damien, Haiti. September 14, 1931, by Dr. H. L. Dozier who sent them to the writer for identification.

Holotype male labeled Damien, Haiti, September 14, 1931.

\section{Explanation of Plate XIII}

(SHOWING MALE GENITALIA)

1 A.-E. gossipii n. sp. lateral view

1 B.-E. gossipii n. sp. ventral view

2 A.-E. canavalia n. sp. ventral view

2 B.-E. canavalia n. sp. lateral view

3 A.-E. fabalis De L. lateral view

3 B.-E. fabalis De L. ventral view Style

-. - . - . . oedagus

-... -..- lateral process of pygopher 


\section{PLATE XIII}
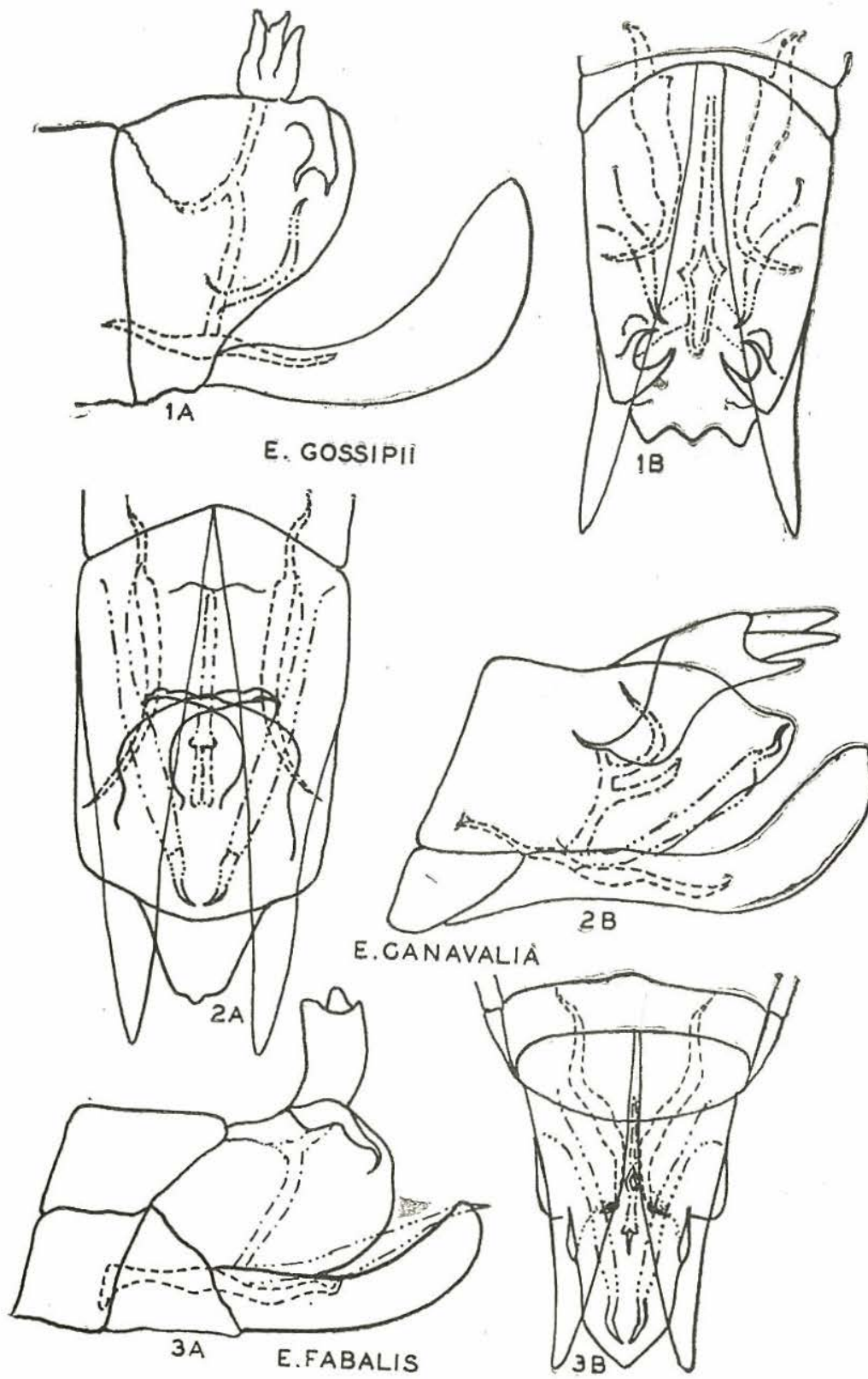


\section{D..}

IMENT OF AGRICULTURE AND COMIMERCE

EDMUN

\section{SUPERIOR OFFICERS}

JAIME B. CoLON, M. S.-_-_-_Commissioner INSO

F. LÓPEZ DOM

R EXPERIMENT STATION STAFF

Sub-Commissioner

vEZ, B. S.-_-_-_Director

J. AMedée Bonet, tVISION OF SOILS

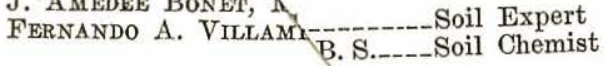

DIVISIO

Thomas BRegger, Ph. D..._._. Plant Breeder

DIVISION OF AGRICUL

Mandel L. Vicentf, C. E., M. E. - gineer

$$
\text { DIVISION OF CHEM, }
$$

RAFAEL ARRoyo, B. S., S. E.-_._-_Chem

José H. RAMf́REz, B.S._-_._._First A lytical Chemist

Héctor CRuz Monclova, B. S...--Second A lytical Chemist

\section{DIVISION OF ENTOMOLOGY}

Mortimer D. Leonard, Ph. D....-Entomologist

Francisco Sefín, JR., B. S._._-_._Assistant Entomo gist

$$
\text { DIVISION OF PHYTOPATHOLOGY }
$$

Melville T. Cook, Ph. D._._-_._Phytopathologist

ARTURo Roque, M. S._._._._._Assistant Phytopathologit

\section{DIVISION OF ZOOTECHNICS}

W. Montgomery Ellison, B. S.--Chief.

Migunl García Díaz, B. S._._...Assistant Chief

Carlos J. Clavele, B. S._-_-Poultry and Rabbit Specialist

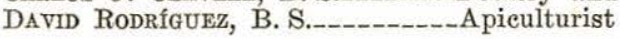

\section{DIVISION OF PHYTOTECHNICS}

Pedro Richardson Kuntz, B. S...-Chief, Cane Specialist

Vicente Medina, B. S._._._-_Coffee Specialist

Fernando Chardon, B. S....... Tobaceo Specialist

Edarund H. Twight, M. S.______ Fruit Specialist

PEDRo OSUNA, B. S._._._._._Horticulturist

FERDINAND MÉNDEZ, B. S._._-_-_Cocoanut Specialist

E. Molinary Salés, B. S._._-_Minor Crop Specialist

J. PASTOR Rodrf́guez, B. S._....-Cotton Specialist

LIBRARY AND. PUBLICATIONS

JosÉ I. OTERO_-_-__-_-_-_-_Librarian

OFFICE

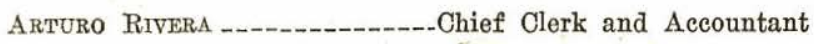

ISABELA SUB-STATION

Luis A. Serrano, B. S._-_-_-_Agronomist in Charge

GEORGe N. WolcotT, Ph. D._._._Entomologist 